\title{
THE EFFECT OF E-PROCUREMENT SYSTEM IMPLEMENTATION, COMPETENCE AND COMPENSATION ON EMPLOYEE PERFORMANCE OF GOODS/SERVICES PROCUREMENT
}

\author{
Nenden Maulida Yuliawati, Icih, Asep Kurniawan \\ Sekolah Tinggi llmu Ekonomi Sutaatmadja Subang \\ Email: icih@stiesa.ac.id
}

\begin{tabular}{l} 
INFO ARTIKEL \\
\hline Histori Artikel : \\
Tgl. Masuk : 22-02-2021 \\
Tgl. Diterima : 25-03-2021 \\
Tersedia Online : 31-03-2021 \\
\hline Keywords: \\
E-procurement, \\
competence,compensation, employee \\
performance.
\end{tabular}

\section{ABSTRACT}

This research was conducted to analyze the magnitude of the effect of the partial and simultaneous implementation of the E-Procurement, Competence and Compensation System on the Goods / Services Procurement Employee Performance in Subang Regency.

This research uses quantitative explanatory methods. The population and sample of the study are employees in the New / Service Procurement Unit in Subang Regency, so the total population is 31 people. Data collection methods used in this study are survey methods by distributing questionnaires. Where each respondent is given questions / statements as many as 32 items using a Likert scale. Data is processed using SPSS 22.0 version.

Based on the results of data processing obtained results there is a positive and significant effect for the variable Application of E-Procurement, Competence and Compensation System partially and simultaneously to Employee Procurement of Goods / Services.

\section{INTRODUCTION}

through the procurement of goods / services is important as one of the economic driving forces (Ayu Nedialita, 2013). Government goods and services procurement is an activity to obtain goods and services by the Ministry / Institution / Regional Work Unit / Institution. The process is starting from the planning of needs until the completion of all activities to obtain goods / services, using the State Budget (APBN) / Regional Budget (APBD) (Perpres Number 4 of 2015).
Government goods / service procurement activities are carried out routinely every year by government agencies, in an effort to meet the needs of government activities and also to improve public services. But the fact is, the procurement of goods / services is not as expected. Because the procurement of goods / services is the most vulnerable point of corruption in Indonesia. Throughout 2017, Indonesia Corruption Watch (ICW) noted that there were 158 cases related to corruption in the infrastructure sector in terms of 
procurement of goods / services. As a result, the State lost Rp. 1.5 trillion. As a comparison, in 2016, the State's loss from corruption in procurement of goods/ services in the infrastructure sector was only Rp. 680 billion, or an increase of $120.5 \%$ in 2017. A total of 21 cases occurred in West Java (13\%), 18 in East Java (11\%) and 11 in North Sumatra $(6.9 \%)$ (http: amp.kontan.co.id/news/Negara-rugi-rp15-trilion-dari-korupsi-Procurementgoods- services-throughout-2017 accessed on February 6, 2019)

West Java Province ranks first in corruption cases related to procurement of goods / services. This corruption case reflects the performance of goods / services procurement that cannot absorb the APBN / APBD budget as it should. This is certainly influenced by the procurement of goods / services in the regency that has a stake in it. Corruption cases in the field of goods and services procurement reflect poor employee performance, so it is interesting to examine the performance of procurement personnel.

One of the factors influencing the performance of procurement personnel is the application of e-procurement. The e-procurement system is one of the egovernment implementation programs. The implementation of e-procurement does not only prioritize web sites and online services but also infrastructure of Information and Communication Technology and human resource capacity (Adjei Bamfo at al, 2019). The advantages of e-procurement can be seen from various aspects consisting of price, time and intellectual efficiency (Wang, Zhang, Liu; 2020). The use of eprocurement results in more efficient procurement process costs with shorter time so that it will improve the performance of the procurement department employees.
Indonesia has implemented eprocurement as a system of goods and services procurement since 2002 until now. The e-procurement application is expected to bring many benefits to its users (Panayitou et al., 2004). With this e-procurement, procurement providers get more offers and also a simpler administrative process when compared to conventional procurement of goods and services. As for the providers of goods / services, e-procurement can expand business opportunities, create healthier business competition, open business opportunities openly to anyone and can reduce administrative costs (Jasin et al, 2007)

The implementation of $e$ procurement in Indonesia is assigned to the Government Goods / Services Procurement Policy Agency (LKPP). LKPP has developed a free license based Electronic Procurement System (SPSE) for all government agencies in Indonesia. regulation of goods / services procurement in Subang Regency implemented by the Goods and Services Procurement Work Unit using e-procurement system since January 2013 in accordance with the strategic objectives of the Subang Regency Goods and Services Procurement Service Unit in 2013-2018 which has been determined, namely the percentage of provider selection goods / services through LPSE (100\%).

Another factor that affects the performance of procurement department employees is competency. According to Rizki Anton N. (2010) Eprocurement has obstacles including: lack of human resources who have not mastered IT; there are still some procurement committees that have not mastered the e-procurement application; less careful in making bid documents and others. Increasing employee competency in the procurement of goods / services in 
accordance with Presidential Regulation Number 16 Year 2018 will improve employee performance.

Another factor that must be considered to improve the performance of employees of the Goods / Services Procurement Unit is compensation. Compensation received by employees is a reflection of what they have given or done to government institutions. Providing compensation is one of the factors driving the high work performance (Wiwiet Eka, 2016).

Based on the description of the problem above, researchers are interested in actualizing it in the study with the title "The Effect of $E$ Procurement System Implementation, Competence and Compensation on the Performance of Goods / Services Procurement Employees (Case Study of Subang District Goods / Services Procurement Work Unit)"

\section{Identification of problems}

Do the implementation of the eprocurement,competency and compensation have a positive effect partially and simultaneously on the performance of employees in the procurement of goods / services ?

\section{LITERATURE REVIEW}

\section{Stewardship Theory}

McGregor (1960) in Glinkowska \& Boguslaw (2015) states that stewardship theory is a theory which states that the main motivation for managers is to get satisfaction from the work done in accordance with the interests of the owner. In this study, employees of the procurement department as a steward will improve their performance for the benefit of the community (owner).

\section{Procurement of goods / services}

According to Article 1 paragraph 1 of Presidential Regulation No. 54 of 2010 as last amended by Presidential Regulation No. 16 of 2018 concerning Government Procurement of Goods / services stated that: Procurement of Goods / services is the activity of Goods / Services Procurement by the Ministry / Regional Institution / Apparatus financed by the State Budget / Regional Budget whose processes have been from the identification of needs, to the handover of work results.

Another definition regarding the procurement of goods and services is as expressed by Marbun (2012: 35), namely: Procurement of goods and services is an effort to obtain the desired goods and services carried out on the basis of logical and systematic thinking (the system of thought), following the norm applicable ethics, based on standard procurement methods and processes.

\section{E-procurement}

The definition of e-procurement according to $\mathrm{Wu}$ et al (2007) is: Electronic Procurement (eprocurement) is defined as the use of information technology to facilitate business-to-business transactions for purchases of materials / goods and services. The application of information system technology to facilitate the procurement process in an integrated manner is a phenomenon that constantly gets the attentioned by Rachmawati (2008: 143) said that compensation is given with the aim of providing stimulation to the workforce to improve work performance, efficiency and effectiveness of work productivity 


\section{Hypothesis Framework}

Based on the theoretical basis and previous research, a hypothetical framework can be arranged as presented in the following figure:

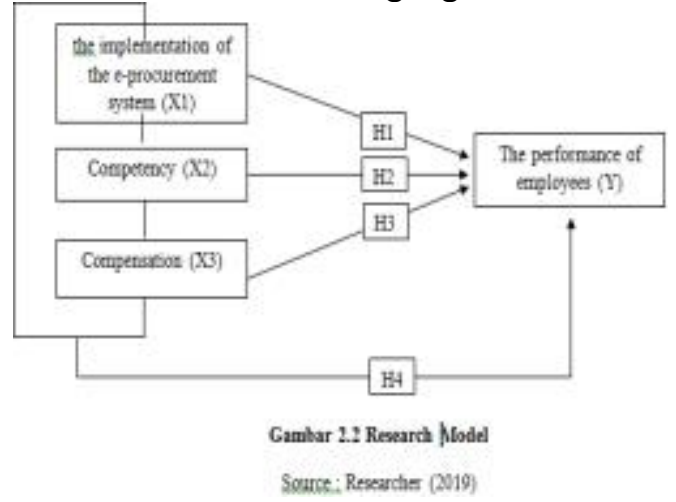

\section{Hypothesis}

Based on the background, the formulation of the problem and the hypothesis framework above, it can be given a hypothesis in this study, namely:

$\mathrm{H} 1$ : The implementation of the eprocurement system has a positive effect on the performance of employees in the procurement of goods / services

According to the Government Goods / Services Procurement Policy Agency (LKPP), the eprocurement system is the procurement of goods / services implemented using information technology and electronic transactions in accordance with statutory provisions. The eprocurement system was developed by LKPP in order to achieve the objective of procurement of government goods / services in accordance with Presidential Regulation No.16 of 2018. This goal is expected to be able to improve the performance of goods / services procurement. Through eprocurement goods / service procurement activities become more effective, efficient, transparent, open, competitive, fair and accountable. This is supported by Viani Utami Tjhin (2016) in her research stating that the adoption of e-procurement affects the performance of procurement / procurement.

H2: Competence has a positive effect on the performance of employees in the procurement of goods / services

According to Law No. 20/2003 concerning National Education System article 35 (1), Competency is the work ability of each individual which includes attitudes, knowledge and skills in accordance with agreed national standards. Based on Presidential Regulation No. 16 of 2018 that Human Resources for Procurement of Goods / Services consists of the management of the procurement of goods / services within the Ministry / Agency / Regional Government and those who have competence in the field of procurement of goods / services. Employees' competency is a measure of the extent to which employees are able to master knowledge and skills. This is supported by A.H. Rahadian and Irman Gapur (2016) in their research stated that competence had a positive effect on the performance of goods / services procurement offices.

H3: Compensation has a positive effect on the performance of employees in the procurement of goods/services.

According to Rachmawati (2008: 143) said that compensation is given with the aim of providing stimulation to the workforce to improve work performance, efficiency and effectiveness of work productivity. Adequate compensation is the most powerful motivational tool for companies to encourage employees to work well. Therefore to improve work performance and productivity must provide appropriate compensation to employees in accordance with the ability of the institution / company itself (Sutrisno, 2009: 189). This is supported 
by Heru Pratama (2017) in his research stating that compensation has a positive effect on performance.

$\mathrm{H} 4$ :Application of e-procurement systems, competencies and compensation have a positive effect on the performance of employees in the procurement of goods / services.

According to the Government Goods / Services Procurement Policy Agency (LKPP), the e-procurement system is the procurement of goods / services implemented using information technology and electronic transactions in accordance with statutory provisions. The purpose of implementing e-procurement is expected to be able to improve the performance of employees in the procurement of goods / services. Apart from the application of the eprocurement system, another thing that can improve the performance of employees in the procurement of goods / services is the competency of the employee. Employees' competency is a measure of the extent to which employees are able to master knowledge and skills, especially in the field of goods / services procurement. The compensation factor is another supporting factor in improving the performance of employees in the procurement of goods / services. Adequate compensation is the most powerful motivational tool for companies to encourage employees to work well.

\section{RESEARCH METHODOLOGY}

\section{Research methods}

This research is included in research with quantitative data using survey methods giving questionnaires / tests to respondents to get primary data (Sugiyono, 2009).

\section{Operational Definition}

The operational definitions and measurement scales used in this study are explained in the following table:
Table 1

Identification of Variable Operations

\begin{tabular}{|c|c|c|}
\hline \begin{tabular}{|l|} 
Researc \\
h \\
variable
\end{tabular} & Definition & $\begin{array}{l}\text { Scale } \\
\text { Measurement }\end{array}$ \\
\hline \begin{tabular}{|l|} 
Applicatio \\
$n \quad$ of $\quad E-$ \\
Procurem \\
ent \\
System \\
$(\mathrm{X} 1)$
\end{tabular} & $\begin{array}{l}\text { Electronic procurement }(\mathrm{e}- \\
\text { procurement) is the } \\
\text { procurement of goods / services } \\
\text { carried out using information } \\
\text { technology and electronic } \\
\text { transactions in accordance with } \\
\text { statutory provisions. } \\
\text { (Www.lkpp.go.id) }\end{array}$ & $\begin{array}{l}\text { Likert Scale } \\
1-5\end{array}$ \\
\hline \begin{tabular}{|l} 
Compete \\
nce (X2)
\end{tabular} & $\begin{array}{l}\text { Competence is the work ability } \\
\text { of each individual which } \\
\text { includes attitudes, knowledge } \\
\text { and skills in accordance with } \\
\text { agreed national standards (Law } \\
\text { No. 20/2003 on National } \\
\text { Education System Article } 35(1) \text { ) }\end{array}$ & $\begin{array}{l}\text { Likert Scale } \\
1-5\end{array}$ \\
\hline \begin{tabular}{|l|} 
Compens \\
ation (X3)
\end{tabular} & $\begin{array}{l}\text { Compensation is the entire } \\
\text { remuneration received by } \\
\text { employees as a result of } \\
\text { carrying out work in the } \\
\text { organization in the form of } \\
\text { money or other (Hariandja, } \\
2007: 244)\end{array}$ & $\begin{array}{l}\text { Likert Scale } \\
1-5\end{array}$ \\
\hline \begin{tabular}{|l} 
Employe \\
e \\
Performa \\
nce (Y)
\end{tabular} & $\begin{array}{l}\text { Performance is work in terms of } \\
\text { quality and quantity achieved by } \\
\text { an employee in carrying out } \\
\text { their duties in accordance with } \\
\text { the responsibilities given to him } \\
\text { (Mangkunegara, 2012: 9) }\end{array}$ & $\begin{array}{l}\text { Likert Scale } \\
1-5\end{array}$ \\
\hline
\end{tabular}

\section{Multiple Linear Regression Analysis}

According to Sugiyono (2014) generally the multiple regression equation is stated in the equation as follows:

$$
Y=a+\beta 1 X 1+\beta 2 X 2+\beta 3 X 3+e
$$

Information :

$$
\begin{array}{ll}
\mathrm{Y} & =\text { The performance of } \\
\text { employees } & \\
\mathrm{A} & =\text { Constanta } \\
\beta 1 \ldots \beta 3 & =\text { Coefisien } \\
\mathrm{X} 1 & \text { The } \\
\text { implementation of the e- } \\
\text { procurement } & \text { system } \\
\mathrm{X} 2 & =\text { Competence } \\
\mathrm{X} 3 & =\text { Compensation } \\
\mathrm{e} & =\text { Error }
\end{array}
$$

\section{RESULTS AND DISCUSSION}




\section{Multiple Linear Regression Test}

Results

Below is a statistical test of the

results

Table 2

Results of Multiple Regression Analysis

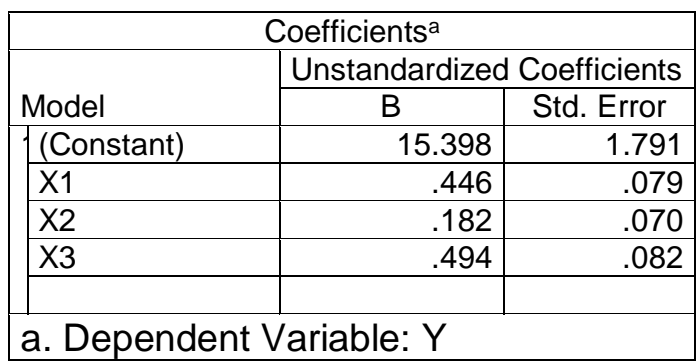

The multiple linear regression equation can be arranged as follows:

$Y=\beta 0+\beta 1 X 1+\beta X 2+\beta X 3+e$

$Y=15.398+0,446 X 1+0,182 X 2+$

$0,494 \times 3+\varepsilon$

\section{Determinant Coefficient $\left(\mathbf{R}^{\mathbf{2}}\right)$}

Below is the result of the determinant coefficient :

\section{Table 3}

The results of the measurement of the correlation coefficient and the coefficient of determination of the independent variables on the dependent variable

Model

Summary

\begin{tabular}{|c|c|c|c|c|}
\hline Model & $\mathrm{R}$ & $\begin{array}{c}\mathrm{R} \\
\text { Square }\end{array}$ & $\begin{array}{c}\text { Adjusted R } \\
\text { Square }\end{array}$ & $\begin{array}{c}\text { Std. Error of } \\
\text { the Estimate }\end{array}$ \\
\hline 1 & $.985^{\mathrm{a}}$ & .970 & .967 & .687 \\
\hline
\end{tabular}

a. Predictors: (Constant), X1,X2,X3

\section{Simultaneous Test (F Test)}

Based on table 4 in the sig column. Table 4

\section{Statistical Test Results F ANOVA $^{a}$}

Tabel 1

Hasil Uji Regresi

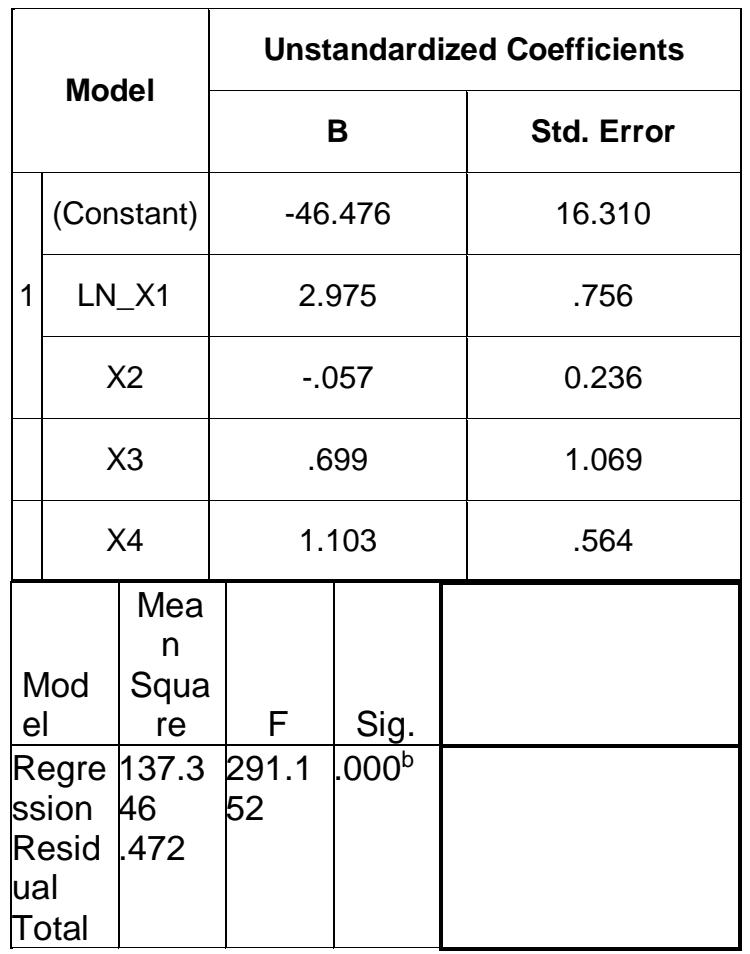

a. Dependent Variable: $Y$

b. Predictors: (Constant), X1,X2,X3.

it can be seen that the significance value is 0,000 , because the model has a probability value of less than 0.05 and based on simultaneous tests, the output results are Fcount $(291,152)>$ Ftable $(2.95)$ so it can be concluded that the performance of employees in the procurement of goods / services is influenced by the application of the e procurement (X1), competence (X2) and compensation (X3) have a significant effect on the performance of employees in the procurement of goods / services $(Y)$.

\section{Partial Test (t test)}

Below are the partial test results of all the independent variables on the dependent variable: 
Table 5

Partial Hypothesis Testing $X$ against $Y$ (T Test)Uji Parsial (Uji t)

\begin{tabular}{|c|c|l|}
\hline Variabel & $\mathrm{T}$ & Sig. \\
\hline $\mathrm{X} 1$ & 5.629 & .000 \\
\hline $\mathrm{X} 2$ & 2.585 & .015 \\
\hline $\mathrm{X} 3$ & 6.056 & .000 \\
\hline \multicolumn{2}{|c|}{ Dependent Variable: $\mathrm{Y}$}
\end{tabular}

This test aims to determine whether there is influence between the independent variable $(X)$ and the dependent variable (Y) partially.

Variable $X 1$ has a calculated $t$ value greater than the $t$ table value. Because the value of $t$ arithmetic (5.629)> t table (2.052) then $\mathrm{H} 1$ is accepted.

Variable $\mathrm{X} 2$ has a calculated $t$ value greater than the $\mathrm{t}$ table value. Because the value of $t$ arithmetic (2.585)> $t$ table (2.052) then $\mathrm{H} 2$ is accepted.

The X3 variable has a calculated $t$ value greater than the $t$ table value. Because the value of $t$ arithmetic (6.056)> $t$ table (2.052) then $\mathrm{H} 3$ is accepted.

\section{Discussion of Research Results}

The following will be discussed discussion about the results of hypothesis testing:

1. The Implementation of EProcurement System Has a Positive Impact on the Performance of Goods / Services Procurement Employees

Based on the responses of respondents that with the implementation of e-procurement, making the procurement package becomes more efficient. Making and announcing packages of goods and services auctions is faster. Eprocurement reduces direct contact between procurement employees and providers of goods and services, thereby reducing fraud. By using e-procurement the auction evaluation will be more optimal and more transparent. Determination and announcement of auction winners is more transparent with a fast rebuttal process. Some of these changes cause employee performance to improve, so it can be concluded that the implementation of the eprocurement system has a significant effect on the performance of employees in the procurement of goods / services. This result is consistent with A.H. Rahadian and Irman Gapur (2016) that the implementation of the eprocurement system has a positive effect on the performance of the procurement of goods / services.

2. Competence Has a Positive Impact on the Performance of Goods / Services Procurement Employees

The competence of
procurement employees is demonstrated by the ownership of certificates of expertise in the procurement of goods / services by the majority of employees with long tenure and a relatively long work period in the procurement department. These things cause an increase in employee performance so it can be concluded that competence has a significant positive effect on employee performance in the procurement of goods / services. These results are consistent with the results of research $\mathrm{H}$. Pratama (2017) that competence has an influence on performance.

\section{Compensation has a Positive}


Effect on the Performance of Goods / Services Procurement Employees

The salary policy for the employees of the Subang Regency procurement department has calculated the level of salary eligibility based on rank and class. Employees are given incentives that are calculated correctly. Employees are given benefits based on rank and class. Employees are given complete facilities. These policies lead to an increase in the performance of employees in the procurement of goods and services so that it can be concluded that compensation has a significant positive effect on the performance of procurement employees. These results are in line with $\mathrm{H}$. Pratama (2016) showing that compensation has a significant effect on performance.

4. Application of E-Procurement, Competence and Compensation Systems Affect the Performance of Goods / Services Procurement Employees

The implementation of eprocurement that provides various benefits in carrying out procurement tasks, the existence of reliable competence and proper compensation affects the performance of employees in the procurement of goods and services in Subang Regency. Some improvements in employee performance include rarely making mistakes in carrying out tasks, working swiftly and quickly, achieving the level of work volume produced in accordance with organizational expectations, completing tasks with full responsibility, maintaining the confidentiality of the auction process, timely work attendance and willingness to cooperate with people Other or fellow UKPBJ members and willingness to accept the opinions of coworkers

\section{CONCLUSION}

Based on the results of data processing obtained results there is a positive and significant effect for the variable Application of E-Procurement, Competence and Compensation System partially and simultaneously to Employee Procurement of Goods / Services.

\section{IMPLICATIONS AND LIMITATIONS}

\section{Limitation}

This study has limitations including:

1. This study only takes one object of government research, namely the Goods / Services Procurement Work Unit. This gives the possibility that this research will reduce the ability to generalize findings.

2. This research is subjective or based on respondents' perceptions.

\section{Suggestion}

Research suggestions as follows: Future studies can add new variables that affect employee performance, including employee empowerment.

\section{REFERENCES}

A.A Anwar Prabu Mangkunegara. (2005). Manajemen Sumber Daya Manusia Perusahaan. Bandung : PT Remaja Rosdakarya

A.H. Rahardian dan Irman Gapur. (2015). Pengaruh E-Procurement Dan Kompetensi Terhadap Kinerja Kantor Layanan Pengadaan Barang/Jasa Kabupaten Bogor

Anton, R.N. (2010). Evaluasi Pelaksanaan E-Procurement di Lingkungan Kota Tegal 
Bamfo, P.A., Nyamekye, T.M., \& Ahenkan A. (2019). The role of e-government in suistainable public procurement in developing countries : A systematic literature review. Resources, Conservation \& Recycling 142, 189 203.

Fang, Wu, Anthony, George. (2007). Antecedents and Outcomes of EProcurement Adoption: An Integrative Model. IEEE Transactions on Engineering Management 54(3):576-587

Glinkowska, Beata dan Boguslow Kaczmarek. 2015. Clasiccal and Modern Concepts of Corporate Governance (Stewardship Theory and Agency Theory) Managemen Vol. 19 No. 2 ISSN 1429-9321

Hasibuan, Malayu. (2000) Organisasi dan Motivasi, Edisi Revisi, Bumi Aksara, Jakarta.

Jasin, M, dkk, (2007). Mencegah Korupsi Melalui E-Procurement, Meninjau Keberhasilan Pelaksanaan EProcurement Di Pemerintahan Kota Surabaya, KPK, Jakarta.

Mangkunegara, Anwar Prabu. (2005) Evaluasi kineria SDM . Cetakan Pertama, Bandung: Refika Aditama

Marbun, Rocky, (2012) Tanya Jawab Seputar Tata Cara Pengadaan Barang/Jasa Pemerintah, Visimedia, Jakarta.

Nedialita, A. (2014). Kinerja Panitia Pengadaan Barang dan Jasa Secara Eletronik (E-Procurement) di Unit Layanan Pengadaan (ULP) Pemerintah Kota Surabaya, Vol 1, No.1
Nurcahyati, Wiwiet Eka, (2016). Pengaruh Kompensasi dan Lingkungan Kerja terhadap Kinerja Karyawan, Vol 3, No.2

Panayiotou, N.A., Gayaialis, S.P., Tatsiopoulus, I.P. (2004), "An Eprocurement ment system for governmental purchasing", International Journal of Production Economics, Vol.90, Hal. 79-102

Pratama, H. (2016). Pengaruh Kompetensi, Komunikasi Dan Kompensasi Terhadap Kelompok Kerja Pada Unit Layanan Pengadaan Pemerintah Provinsi Kalimantan Timur

Purwanto, Erwan Agus, (2008), eprocurement di Indonesia, Jakarta : Kemitraan

Rachmawati, Ike Kusdyah, (2008). Manajemen Sumber Daya Manusia, Edisi Pertama. Yogyakarta

Siahaya, Willem. (2012). Manajemen Pengadaan Procurement Management. Bandung, Alfabeta

Sugiyono, (2009) Metode Penelitian Bisnis (Pendekatan Kuantitatif, Kualitatif dan R\&D). Bandung.

Sutrisno, Edy. (2009) Manajemen Sumber Daya Manusia. Jakarta : Kencana Prenadamedia Group

Wang, Q., Zhang, R., Liu, J. (2020). Price/ time/ intellectual efficiency of procurement : Uncovering the related factors in Chinese public authorities. Journal of Purchasing and Supply Management. 